Open Access

\title{
Entrepreneurship in an open national innovation system (ONIS): a proposal for Mexico
}

\author{
Leonel Corona-Treviño
}

\author{
Correspondence: \\ leonel.corona.trevino@gmail.com \\ Universidad Nacional Autonoma de \\ Mexico, Mexico City, Mexico
}

\begin{abstract}
In the context of globalization, international processes do affect the national innovation system (NIS), increasing the relationship between its agents and its components within and with external agents.

The paper seeks to determine the openness and internationalization processes in the internal features of Mexico's NIS and estimate its impacts. This information could allow for a better use of scientific, technological, and innovation -internal and external_capabilities.

The point of departure is the concept of innovation, which was developed for the industrial revolution where products and technological processes are emphasized, with a scope of radical to incremental innovation, as a function of the level of their impacts. Implicitly, innovation has been conceptualized internally within the company, i.e., closed innovation, especially in large companies with research and development departments. However, companies have undertaken various forms of collaboration to reduce costs particularly for $R \& D$, which fall within the concept of open innovation. Based on the concept of open innovation, an open national innovation system (ONIS) has been proposed with internal and external components and relationships.

This paper argues that the openness of innovation needs to be applied both at firm level and through a NIS as a way of handling the risks involved in innovation better. Thus, firms' open innovation must correspond to an ONIS, matching the openness and internationalization of its knowledge components and agents: firms and universities supported through government policies. The empirical analysis is exploratory, based on a direct and indirect source to assess how highly developed the Mexican ONIS is in order to propose some policies.
\end{abstract}

Keywords: National innovation system, Open innovation, Internationalization, KIBS, TBF, Entrepreneurship, Mexico

\section{Background}

At macro level, the openness and the international processes do affect the national innovation system $\left(\mathrm{NIS}^{1}\right)$ by increasing the relationship and collaboration of its agents and components with external agents. One aspect to be measured is determining the impact of the openness and internationalization (OpIn) processes in the (national) internal features of Mexico's NIS, through assessing them within the context of the system's components to facilitate better use of scientific, technological, innovation, and entrepreneurial

(c) 2016 Corona-Treviño. Open Access This article is distributed under the terms of the Creative Commons Attribution 4.0 International License (http://creativecommons.org/licenses/by/4.0/), which permits unrestricted use, distribution, and reproduction in any medium, provided you give appropriate credit to the original author(s) and the source, provide a link to the Creative Commons license, and indicate if changes were made. 
capabilities, both internal and external, considering that both processes are interrelated in different ways and aspects in each component.

Generalizing to a larger context of Schumpeter's concept of innovation (Schumpeter 1934), with the concept of open innovation ${ }^{2}$ and of internationalization processes, an open national innovation system (ONIS) has been proposed with internal and external components and agents and relationships. The components of the ONIS are the businesses and the entrepreneurs, universities, research centers, technology transfer agents, financing-venture capital and "angels" funding, information systems, intellectual property mechanisms, and diverse government participation and regulation.

Opening up innovation and the NIS are motivated by a desire to increase sources of profits and to diminish the risks of capital investments.

An entrepreneur could overcome some capital risks by widening the scope of their relationships. This means modifying the concept of innovation, which was developed for the industrial revolution-where innovation has been conceptualized as occurring within the company, i.e., "closed innovation." So companies, especially those with research and development departments, have undertaken various forms of collaboration to reduce costs, particularly for R\&D, which fall within the concept of "open innovation," thus diminishing their vulnerability.

Universities and research centers can also open knowledge application relationships, linking their lines of research with potential users, participating in international consortia and research networks.

Financing is an international activity, which can be open depending on the risks involved in the innovation phases, which is particularly critical at birth (start-up) when the firm starts marketing a product, the novelty of which is often based on the intensive use of scientific and technological knowledge.

Government policies and incentives could be oriented towards developing innovation capabilities regardless of the internal or external resources. In this context, the Mexican diaspora could be a result of public policies, mainly for qualified people.

\section{Literature review}

\section{National system of innovation}

The NIS creates and disseminates productive knowledge through interrelated institutions. However, the concept departs from the national space as an attempt to understand the variety of national systems. The tendency has been for it to be applied to closed systems, focusing on a country's specific conditions. ${ }^{3}$ Therefore, we should return to the open approach, to be based on aspects and external processes that are conducive to or allow seizing opportunities, preventing obstacles and threats in the generation of knowledge and innovation capabilities, both internally and externally. This implies that the NIS's components besides its internal relations are complemented, or sometimes dominated, by external economic relations and modes of cooperation.

The evolution of the NIS approach can be observed by the inclusion of two aspects: first, the addition of the analysis of services (Howells \& Teller 2004), and particularly of service innovations, characterized in subsequent phases: assimilation, demarcation, and 
synthesis (Coombs \& Miles 2000) (Miles 2008), based on a combination of new and old theories and concepts (Djellal \& Gallouj 2013), and second, the grouping of goods and services (Omachonu \& Einspruch 2014) in a trajectory of interrelationships between the institutions with its context, evolving as an ecosystem of innovation (Jackson 2011).

\section{Open innovation}

Open innovation is "the use of purposive inflows and outflows of knowledge to accelerate internal innovation, and expand the markets for external use of innovation, respectively" (Chesbrough et al. 2006). In general, innovation occurs in a context of waves of "creative destruction" that restructure the whole market in favor of companies that adopt the faster occurring discontinuities. However, the capitalist is usually depicted as the one who manages existing structures, while the relevant issue is how companies are created and destroyed (Schumpeter 1934).

Open innovation is a concept which refers to the way to manage the uncertainty involved in the creation of new businesses, especially in the early stages, in order to increase opportunities for benefits or cost reduction (or both) in different phases of the knowledge process. So, risk-laden activities of innovation could have the advantages of "(i) benefits from early involvement in new technologies or business opportunities; (ii) delayed financial commitment; (iii) early exits reducing the downward losses; and (iv) delayed exit in case it spins off a venture" (Vanhaverbeke et al. 2008; p. 251).

There is no publication in the literature which considers the OpIn processes of NIS. However, there are some implicit considerations such as the idea that the national system of production should not be considered as a closed system (Etzkowitz \& Leydesdorff 2000) or that "the specific degree and form of openness determines the dynamics of each national system of production" (Lundvall 1988).

The dynamics driving the open innovation sources are internationalization processes, collaboration and alliances with other firms (Hertog 2000), advantages based on the potentiality of research, and business models of cooperation (based on (Gassmann et al. 2010); p. 4):

1) Globalization and international division of labor: internationalization of $R \& D$; internationalization of entrepreneurship and migration of talent; outsourcing $R \& D$ and alliances; and segmentation of production chains and value

2) Relations with suppliers and users: integration of supplier and customer participation in the innovation process

3) Leveraging multiplication of research skills and intellectual assets (patents) with collaborative strategies, including new markets

4) Institutional and cultural framework: cooperative model innovation instead of a temporary monopoly profit-based model

\section{Entrepreneurship}

Entrepreneurship is a concept developed to explain the actors of a new wave of firms generating a "creative destruction," as the diffusion of new combinations of resources renders old industries obsolete. The creation of new and better ways of doing business destroys the established ways (Schumpeter 1934). 
Entrepreneurship initiatives resulting from technology transfers have a lower probability of surviving (Valls and otros 2012), as they face a large uncertainty (Reis 2011). This vulnerability can be differentiated according to the business lifecycle-birth, growth, decline, and death-and threats, which vary according to competition (e.g., entry barriers, access to finance, and market rates). In this context, the beginning of the commercialization of a new product, considering the high costs and risks, is called "the valley of death." Risk also depends on the enterprise's stage of development, whether it is in incubation or whether it is already marketing new technologies or products. Indeed, companies that operate and develop new technologies and/or are intensive in the use of knowledge, but especially those that generate innovations, show higher death rates. Added to these difficulties inherent in its business is the innovative when putting products (goods and services) onto the market, or developing new processes (Drejer 2004). The expectations of higher profits from successful ventures must offset the risks involved.

Entrepreneurship is the ability to bring about change (active) and the ability to absorb changes caused by external factors (passive).

The role of the entrepreneur is that of an individual or individuals who carry out the function of combining the factors required to innovate and who may lose this characteristic when, after a period of time, they merely run the business (Schumpeter 1934; p. 88).

Therefore, an entrepreneur is someone who takes a risk, focusing on innovation and improvement that creates upheaval and change. Therefore, the entrepreneur is a disruptor leading to long-run evolutionary growth (Schumpeter 1934). This approach which understands small firms as breakthrough innovators is complemented by large firms who undertake more incremental innovation, playing both critical and complementary roles (Baumol 2002).

However, there are other points of view: entrepreneurship as matching supply and demand by identifying unnoticed profit opportunities. The entrepreneur is a risk taker by offering new solutions in the market in the face of uncertainty about whether their solutions will be profitable. Finally, the entrepreneur could be seen as a resource shifter managing within firms' shift resources from lower to higher productivity activities (OECD 2010; p. 3).

\section{Universities and research centers}

The entrepreneurial university plays a role in NIS as an "umbrella of the selfsteering, self-reliant and progressive university," taking risks, strengthened steering core; expanding developmental periphery; diversifying funding base; stimulating academic heartland; and overall integrating the entrepreneurial culture (Burton 2001).

The evolution of the entrepreneurial universities is linked to the interrelations of universities and research centers with firms and the government, as part of the "triple helix model" (Etzkowitz \& Leydesdorff 2000). The evolution begins with a model of expectation of continuing use and transformation of knowledge in a linear model process (Godin 2006). The second phase "entails a laissez-faire policy, nowadays also advocated as shock therapy to reduce the role of the state in Triple Helix I"; and in the third phase, the institutional spheres are overlapping, "with each taking the role 
of the other and with hybrid organizations emerging at the interfaces" (Etzkowitz \& Leydesdorff 2000).

The context of changes that impact the universities could be summarized in the following tendencies (Davies 2001):

1) "reductions in public financial support which create an imperative for new and diversified financial sources

2) continuing pressure on universities from governments and the industrial sector to develop applied research and make available education in forms of delivery congenial to companies and public sector organizations

3) the lifelong learning movement

4) globalization of higher education in its various forms and

5) the opportunities offered by the information/knowledge society revolution."

6) The triple helix is extended to other agents, ${ }^{4}$ then a fourth agent "society" is added, which is related in different ways to the triple helix. ${ }^{5}$ These interrelations could be coupled to the framework of "mode 1" of knowledge production to basic university research in a disciplinary structure which evaluate to a "mode 2" which focuses on knowledge application and a knowledge-based problem-solving and interdisciplinary (Etzkowitz \& Leydesdorff 2000) (Gibbons et al. 1994).

\section{Government}

The role of governments is oriented towards the regulation, incentives, and promotion and towards public-private partnerships. It has a special function in the internationalization and openness of the economy and the components of the NIS. There is little research on the aspects of governmental policy that help enterprises by facilitating and stimulating the use of a firm's external capabilities and orienting its impacts on the OpIn (De Jong 2008).

\section{Methods}

It is argued that a better solution to managing the risks of innovation is to apply openness in innovations not only at firm level (Chesbrough 2003) but also at the national level with an ONIS framework involving the main agents: firms, universities and research centers, and government.

The working hypothesis is that an ONIS is a better framework which generates entrepreneurship in a society that uses both traditional knowledge and new scientific and technological advances.

From this perspective, globalization processes are levers that increase internal capabilities and opportunities for entrepreneurial activities related to science, technology, and innovation.

The proposal of an ONIS involves several key aspects:

1) Industrial selection based on the intensity of $R \& D$, high technology, and knowledge intensity and innovativeness

2) Support for SMEs either a technology-based firm (TBF) or knowledge-intensive business services $\left(\mathrm{KIBS}^{6}\right)$

3) Interactive learning and testing processes between suppliers and clients for innovation 
4) Fostering collaboration and strategic alliances between companies for innovation and diffusion

5) Exploring outward-looking relationships: in venture capital, technology transfer, partnerships with organizations and companies, international mobility, risk sharing, information networks, and patents

6) Opportunities from internal and external traditional knowledge to "blending" with the new technologies ${ }^{7}$

An analysis of how enterprises are helped to participate in OpIn through government policies in order to commercialize the knowledge originated through $R \& D$, science, and education and in the market (competition, labor market) and in the firms' dynamics (entrepreneurship, interactions) is applied to Mexico (Graf \& Brau 2013).

The Mexican economic system is polarized making it a dual economy with a few big international companies and modern firms on the one hand and many small businesses on the other (op cit. 309). The Mexican NIS is influenced by international agreements, especially NAFTA.

The public innovation incentive is oriented to support firms' R\&D as well as interaction to facilitate the diffusion of scientific knowledge in private and public enterprises. However, the incentives are oriented more towards publishing articles than working in collaboration with enterprises as the public funding system is based on journal citations (op cit. p308). In addition, the firms with a certain degree of innovation can profit from an OpIn.

To measure the innovativeness within the firm's ambit, an Indico index is applied. The index varies between 0 and 10 points summing up two main components: capabilities for innovation and results (output). The first component consists of knowledge capabilities (hardware, information); employee training (certification, studies degrees); R\&D organization and R\&D in \% of sales; and the relationship with knowledge sources. The second are the outputs: innovations, intellectual propriety and markets and product certifications, and service knowledge intensity (Corona-Treviño 2015).

The Indico index is calculated to measure the 42 firms' innovativeness based on the responses of the chief firm's R\&D and/or executives, who reported up to five more important innovations made in either product, process, organization, or marketing during the last 3 years (Appendix).

\section{Results}

The results are twofold, first, the assessment of the openness of the Mexico NIS including its main components and, second, some exploration on the firms' openness.

Mexico's ONIS has components and relationships with strengths and weaknesses (Fig. 1):

1. In relative terms, Mexico has a good training capacity producing qualified personnel based on research center and university teaching and research activities and networking with its international pairs.

2. Mexico's knowledge capacity is good in science, is low in technology, and is poor in indigenous technology transfer and patents. 


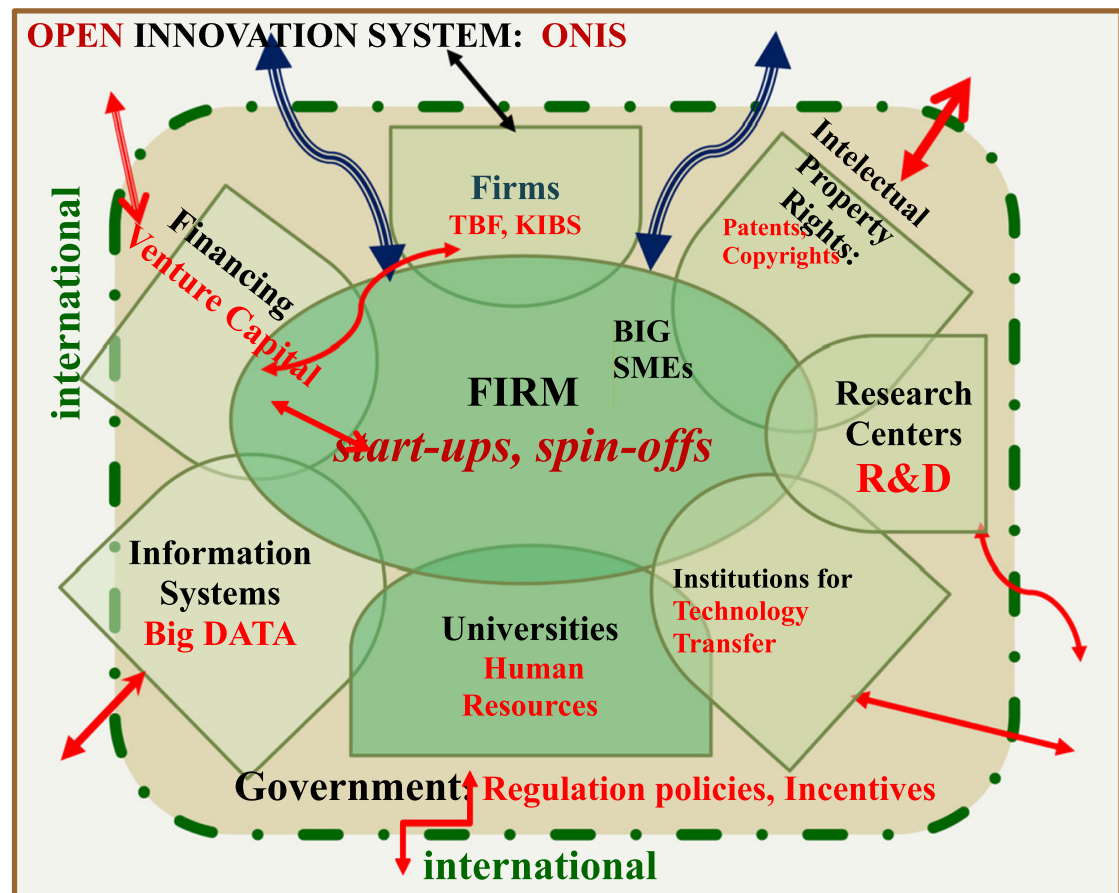

Fig. 1 Open innovation system: ONIS. Source: author's design

3. Patenting by Mexicans is limited ( $3 \%$ in 2013). ${ }^{8}$ To foster it, policies are needed.

(a) To create a positive environment for registering patents and exploiting them and (b) to anticipate the second patenting generation as commercial products besides the present protection and defense mechanisms (Chien 2010)

4. Venture capital and angels for start-ups are scarce, so international sponsorship could contribute a lot if they are willing to consider partnerships with local angels and share the investment risk.

5. Data firms need to be encouraged to handle niches in information growth, in particular big data.

6. Government policies are more oriented to developing capabilities (human resources and researchers) than to drive the innovation dynamics. Besides that, the level of resources on R\&D is low (0.5 \% GDP) compared with other OCDE countries.

7. Mexico's qualified "diaspora" is a strategic complement of the ONIS, considering that some of them are entrepreneurs, patenting and carrying out technology transfers, and participating in international knowledge networking. Students funded by Conacyt, many of whom form part of the Mexican diaspora, have developed technology (6.9\%), have been granted patents (3.9\%), have been entrepreneurs (6.14\%), and report that they have been participating in innovations (12.5\%). This means that in this sector of the diaspora, there are people who could potentially contribute to Mexico's capabilities in these fields.

\section{Start-ups, spin-offs}

As mentioned in the methodology, an Indico index-which is composed of capacity indicators and results-is applied to measure the innovativeness of the firms. The Indico 
Table 1 Innovativeness firms' Indico index

\begin{tabular}{|c|c|c|c|c|c|c|c|c|}
\hline Number & Firm & $\begin{array}{l}\mathrm{KIBS/} \\
\mathrm{TBF}\end{array}$ & $\begin{array}{l}\text { Indico } \\
\text { index }\end{array}$ & Output & Capacity & Efficiency & Industry & $\begin{array}{l}\text { International } \\
\text { index }\end{array}$ \\
\hline 51 & $\begin{array}{l}\text { Impresos técnicos } \\
\text { marno S.A. de C.V. }\end{array}$ & KIBS & 6.78 & 6.55 & 7.01 & 0.94 & Printing & 4 \\
\hline 1 & Praxis & KIBS & 6.73 & 6.39 & 7.08 & 0.90 & Software & 42 \\
\hline 35 & Grupo SSC & KIBS & 6.48 & 5.33 & 7.64 & 0.70 & Software & 0 \\
\hline 49 & $\begin{array}{l}\text { Integral Project IT S. } \\
\text { de R.L. de C.V. }\end{array}$ & KIBS & 6.32 & 5.71 & 6.94 & 0.82 & Software & 3 \\
\hline 31 & Agro\&biotecnia & KIBS & 6.32 & 6.11 & 6.53 & 0.93 & Biotechnology & 0 \\
\hline 10 & BUSINESS INTELLIGENT & KIBS & 6.32 & 4.88 & 7.75 & 0.63 & Software & 10 \\
\hline 33 & Government Solutions & KIBS & 6.30 & 5.86 & 6.74 & 0.87 & Software & 1 \\
\hline 45 & Google Inc. & KIBS & 6.19 & 3.82 & 8.56 & 0.45 & Software & 1 \\
\hline 9 & PIXCOMP & KIBS & 5.82 & 5.32 & 6.32 & 0.84 & $\begin{array}{l}\text { Software } \\
\text { (móvil) }\end{array}$ & 10 \\
\hline 47 & Productos Mahaua & TBF & 5.68 & 4.74 & 6.63 & 0.71 & Design & 0 \\
\hline 32 & Qualsoft & KIBS & 5.67 & 4.13 & 7.20 & 0.57 & Software & 0 \\
\hline 36 & $\begin{array}{l}\text { Grupo QUAE Laboratorio } \\
\text { de Diagnóstico Molecular }\end{array}$ & KIBS & 5.52 & 4.54 & 6.50 & 0.70 & $\begin{array}{l}\text { Health } \\
\text { molecular } \\
\text { diagnosis }\end{array}$ & 0 \\
\hline 14 & Uno uno cero uno & KIBS & 5.40 & 4.99 & 5.81 & 0.86 & Software & 2 \\
\hline 15 & Factor Evolución & KIBS & 5.29 & 4.54 & 6.04 & 0.75 & Software & 4 \\
\hline 44 & $\begin{array}{l}\text { Mesquite Tech } \\
\text { S.A. de C.V. }\end{array}$ & KIBS & 5.23 & 4.35 & 6.12 & 0.71 & Software & 103 \\
\hline 34 & BrainUp Systems & KIBS & 5.19 & 4.44 & 5.95 & 0.75 & Software & 6 \\
\hline 4 & Innovaweb & KIBS & 5.17 & 4.59 & 5.75 & 0.80 & Software & 0 \\
\hline 39 & $\begin{array}{l}\text { Ideo Gráficos \& } \\
\text { Publicidad S.A. de C.V. }\end{array}$ & KIBS & 5.14 & 2.65 & 7.62 & 0.35 & Publicity & 4 \\
\hline 6 & WEXLER & TBF & 5.11 & 4.76 & 5.46 & 0.87 & Autoparts & 25 \\
\hline 46 & $\begin{array}{l}\text { Sociedad de Ingeniería } \\
\text { Especializada de } \\
\text { Occidente SA de CV }\end{array}$ & KIBS & 5.01 & 3.62 & 6.40 & 0.57 & Engineering & 5 \\
\hline 48 & Grupo Financiero Banorte & KIBS & 4.73 & 3.44 & 6.02 & 0.57 & Finance & 23 \\
\hline 42 & Grupo Nacer Global & KIBS & 4.52 & 4.91 & 4.12 & 1.19 & Education & 3 \\
\hline 38 & $\begin{array}{l}\text { Alimentos Nutracéuticos } \\
\text { Bioprocesados SAPI de CV }\end{array}$ & TBF & 4.42 & 1.43 & 7.41 & 0.19 & Food & 0 \\
\hline 40 & Wender \& Wender & KIBS & 4.41 & 2.47 & 6.34 & 0.39 & $\begin{array}{l}\text { Design } \\
\text { graphic }\end{array}$ & 0 \\
\hline 18 & Comparte Vida & TBF & 4.37 & 2.56 & 6.18 & 0.41 & Health & 0 \\
\hline 12 & REDRABBIT & KIBS & 4.34 & 3.38 & 5.29 & 0.64 & Software & 5 \\
\hline 2 & PROSA & KIBS & 4.34 & 4.76 & 3.91 & 1.22 & $\begin{array}{l}\text { Informatics } \\
\text { finance }\end{array}$ & 12 \\
\hline 8 & WRP & KIBS & 4.19 & 3.73 & 4.64 & 0.80 & Software & 0 \\
\hline 11 & RQ PORTILLO & KIBS & 4.13 & 3.81 & 4.45 & 0.86 & Software & 0 \\
\hline 52 & Argeomática SA de CV & KIBS & 3.92 & 1.87 & 5.96 & 0.31 & Software & 0 \\
\hline 5 & CustomSoft & KIBS & 3.86 & 3.94 & 3.78 & 1.04 & Software & 20 \\
\hline 50 & $\begin{array}{l}\text { INDUSTRIA ZÜDHER } \\
\text { S.A. DE C.V. }\end{array}$ & TBF & 3.83 & 3.01 & 4.65 & 0.65 & Transport & 90 \\
\hline 41 & $\begin{array}{l}\text { CLEMENTE CAMARA Y } \\
\text { ASOCIADOS PUBLICIDAD } \\
\text { S.A. DE C.V. }\end{array}$ & KIBS & 3.66 & 2.14 & 5.18 & 0.41 & Publicity & 0 \\
\hline 17 & ONE CARD & KIBS & 3.24 & 1.23 & 5.25 & 0.23 & Software & 1 \\
\hline
\end{tabular}


Table 1 Innovativeness firms' Indico index (Continued)

\begin{tabular}{lllllllll}
\hline 53 & PIENSA GRAM SERVICE & KIBS & 3.24 & 2.19 & 4.30 & 0.51 & Finance & 0 \\
& S.A. DE C.V. & & & & & & & \\
43 & UBER MEXICO AC RL & KIBS & 3.21 & 3.34 & 3.07 & 1.09 & Transport & 5 \\
19 & Biocris & TBF & 3.19 & 2.38 & 4.00 & 0.60 & Health & 0 \\
7 & CIA & KIBS & 3.12 & 2.92 & 3.32 & 0.88 & $\begin{array}{l}\text { Design } \\
\text { dressing }\end{array}$ & 0 \\
16 & CENTRO DE & KIBS & 2.28 & 1.59 & 2.96 & 0.54 & Consulting & 0 \\
& DESARROLLO & & & & & & & \\
13 & $\begin{array}{l}\text { Amplemind Technology } \\
\text { Agency }\end{array}$ & KIBS & 1.47 & 0.89 & 2.05 & 0.44 & Software & 20 \\
\hline
\end{tabular}

${ }^{a}$ International index is the sum of international firm's sales, patents, relations, and certificates. Source: based on data collected directly from author's interviews with firms

index for all the 41 firms shows a range from 6.78 down to 1.47 with an average of 4.77, highlighting a group of 21 firms with above average rating. In the top 10 Indico index (more than 5.7 points), nine are KIBS and one is a TBF, so that innovativeness slants towards service firms (Table 1).

Considering an efficiency index-calculated by the relation between output over capacity-the first rank varies from 1.22 (Prosa) down to 0.19 (ANB). The average tendency is 1.37 points of innovativeness by one unit of efficiency (though it is not statistical accepted).

The firms show a pattern of external participation involving other agents in their innovations. On one hand, half of the TBF, ( 3 out of 6 TBFs) and one third of the KIBS (12 out of 35) do their innovations internally. On the other hand, firms' innovations developed with external participation are (1) working in partnership suppliers (5 KIBS and $1 \mathrm{TBF}$ ); (2) clients' participation (9 KIBS); and (3) collaborating two external agents either outsourcing suppliers or clients (7 KIBS). "Innovation chains" is with three external agents joining forces with the firm (1 KIBS-SIEO, 1 TBF-Mahaua) and is subcontracting the whole innovation, which is without internal participation (1 KIBS-"Comparte Vida," 1 TBF-Biocris). The $56 \%$ of the firms have either sales, intellectual property, linkages, or certificates, with international relationships which most of them (61 \%) have an innovativeness index above the average (Table 2).

\section{Discussion}

The current crossroads in Mexico of growing qualified unemployment, as a result of a stagnant economy that generates few jobs, could be partially reversed by productive policies and incentives and also by facilitating the channeling of funds to promote, among other things, technological and knowledge-intensive entrepreneurship services. Both the open innovation of TBFs and KIBS in a framework of ONIS could facilitate policies that allow a better use of the knowledge flows concatenated with the internationalization of entrepreneurship and enterprises in general. One possible source of change could come from the Mexican diaspora. Of 100 Conacyt scholars who stayed abroad, 6 have been entrepreneurs, or involved in technology development; 4 have been granted 
Table 2 Collaboration in the innovation \%

\begin{tabular}{|c|c|c|c|c|c|c|c|c|c|}
\hline 离 & FIRM & 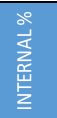 & 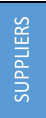 & $\begin{array}{l}0 \\
\frac{0}{2} \\
0 \\
0 \\
0 \\
5 \\
0 \\
0\end{array}$ & 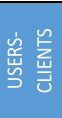 & 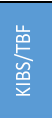 & INNOVA & $\begin{array}{l}\text { ONNDRIVEN BY } \\
\text { AGENTS }\end{array}$ & INDUSTRY \\
\hline 5 & Customsoft & 100 & 0 & 0 & 0 & KIBS & \multirow{15}{*}{1} & \multirow{14}{*}{$\begin{array}{c}\text { Internal } \\
\text { (KIBS/ } \\
\text { TBF) }\end{array}$} & Software \\
\hline 6 & WEXLER & 100 & 0 & 0 & 0 & TBF & & & autoparts \\
\hline 7 & CIA & 100 & 0 & 0 & 0 & KIBS & & & clothing design \\
\hline 10 & BUSINESS INTELLGGEI & 100 & 0 & 0 & 0 & KIBS & & & Software \\
\hline 11 & RQ PORTILLO & 100 & 0 & 0 & 0 & KIBS & & & Software \\
\hline 12 & REDRABBIT & 100 & 0 & 0 & 0 & KIBS & & & software \\
\hline 16 & CENTRO DE DESARRO & 100 & 0 & 0 & 0 & KIBS & & & consulting \\
\hline 31 & Agro\&biotecnia & 100 & 0 & 0 & 0 & TBF & & & Biotech \\
\hline 32 & Quals oft & 100 & 0 & 0 & 0 & KIBS & & & software \\
\hline 33 & Government Solutio & 100 & 0 & 0 & 0 & KIBS & & & software \\
\hline 36 & Grupo QUAE Laborat & 100 & 0 & 0 & 0 & KIBS & & & Health \\
\hline 38 & Alimentos Nutracéu1 & 100 & 0 & 0 & 0 & TBF & & & food \\
\hline 42 & Grupo Nacer Global & 100 & 0 & 0 & 0 & KIBS & & & education \\
\hline 48 & Grupo Financiero Ba & 100 & 0 & 0 & 0 & KIBS & & & finance \\
\hline 51 & Impresos técnicos $N$ & 0 & 0 & 0 & 100 & KIBS & & Clients & printing \\
\hline 17 & ONE CARD & 80 & 20 & 0 & 0 & KIBS & \multirow{15}{*}{2} & \multirow{6}{*}{$\begin{array}{c}\text { Internal } \\
\text { \&Suppliers }\end{array}$} & software \\
\hline 40 & Wender \& Wender & 10 & 90 & 0 & 0 & KIBS & & & Graphic Design \\
\hline 41 & CLEMENTE CAMARA Y & 70 & 30 & 0 & 0 & KIBS & & & Publicity \\
\hline 45 & Google Inc. & 66.7 & 33.3 & 0 & 0 & KIBS & & & software \\
\hline 50 & INDUSTRIA ZÜDHER ! & 50 & 50 & 0 & 0 & TBF & & & autoparts \\
\hline 52 & Argeomática SA de C & 20 & 80 & 0 & 0 & KIBS & & & software \\
\hline 1 & Praxis & 67.5 & 0 & 0 & 32.5 & KIBS & & \multirow{9}{*}{$\begin{array}{l}\text { Internal } \\
\text { \&clients }\end{array}$} & software \\
\hline 8 & WRP & 60 & 0 & 0 & 40 & KIBS & & & software \\
\hline 9 & PIXCOMP & 60 & 0 & 0 & 40 & KIBS & & & software (móvil) \\
\hline 13 & Amplemind Technol & 50 & 0 & 0 & 50 & KIBS & & & software \\
\hline 15 & Factor Evolución & 72 & 0 & 0 & 28 & KIBS & & & software \\
\hline 35 & Grupo Ssc & 50 & 0 & 0 & 50 & KIBS & & & software \\
\hline 37 & Kampa Tlatlatia A.c. & 95 & 0 & 0 & 5 & KIBS & & & social innovation \\
\hline 39 & Ideo Gráficos \& Publ & 33.3 & 0 & 0 & 66.7 & KIBS & & & Publicity \\
\hline 44 & Mesquite Tech S.A. d & 33.3 & 0 & 0 & 66.7 & KIBS & & & software \\
\hline 14 & Uno uno cero uno & 81.3 & 0 & 2.5 & 16.25 & KIBS & \multirow{9}{*}{3} & \multirow{2}{*}{$\begin{array}{l}\text { Internal \& } \\
\text { outsourcing } \\
\text { \& clients }\end{array}$} & software \\
\hline 43 & UBER MEXICO AC RL & 66.7 & 0.0 & 16.7 & 16.7 & KIBS & & & Transport \\
\hline 2 & PROSA & 58.25 & 2.5 & 0 & 39.25 & KIBS & & Internal \& & finance infomatic \\
\hline 4 & Innovaweb & 59 & 21 & 0 & 20 & KIBS & & suppliers & informatica \\
\hline 34 & Brainup Systems & 80 & 10 & 0 & 10 & KIBS & & +clients & software \\
\hline 53 & PIENSA GRAM SERVIC & 50 & 25 & 0 & 25 & KIBS & & \multirow{4}{*}{$\begin{array}{l}\text { external } \\
\text { Innovatio }\end{array}$} & finance \\
\hline 49 & Integral Project ITS. & 83.3 & 0.0 & 16.7 & 0 & KIBS & & & software \\
\hline 18 & Comparte vida & 0 & 50 & 25 & 25 & KIBS & & & health \\
\hline 19 & Biocris & 0 & 5 & 5 & 90 & TBF & & & health \\
\hline 46 & SIEO, Sociedad de II & 36.7 & 43.3 & 3.3 & 16.7 & KIBS & \multirow{2}{*}{4} & \multirow{2}{*}{$\begin{array}{l}\text { internal \& } \\
\text { innovatio }\end{array}$} & Engineering \\
\hline 47 & Productos Mahaua & 90.0 & 3.3 & 3.3 & 3.3 & TBF & & & Design \\
\hline
\end{tabular}

Source: Based on data collected directly from author's interviews with firms

patents; and 12 have participated in innovations. These capabilities could be very useful in an ONIS.

\section{Conclusions}

Mexico lags behind other countries with a higher or similar level of scientific and technological (S\&T) development. This is due to the difference between, on the one hand, the relatively significant S\&T capacities developed in the country's higher education institutions and public research centers and, on the other hand, a rather low level of dynamism in the creation of knowledge-based start-ups.

In this context, openness in the ONIS components is proposed, in particular those related with the application and use of knowledge in production, that is, in firms and start-ups, both TBFs and KIBSs: technology development, technology transfer, intellectual property, and financing through venture capital and angels funds.

However, for this to occur, active policies will be necessary on the part of government, research centers, universities, and firms. 
An exploratory study of 41 start-ups, based on an Indico index, suggests that KIBS are more innovative ( 4.8 vs 4.4 , respectively) and more efficient ( 0.72 vs 0.57 , respectively) than TBFs.

On one hand, openness with respect to innovation is observed in two thirds of the 35 KIBS and in half of the TBF; the rest handle innovation internally. Ten percent of firms have an innovation chain that is innovating with the participation of clients, suppliers, and subcontractors. On the other hand, the firms' internationalization is positively related to its innovativeness.

To sum up, the OpIn of innovation needs to be applied both at firm level and through an open NIS as a way of increasing firms' innovativeness and creating a positive environment through which to manage the risks involved in innovation.

\section{Endnotes}

${ }^{1}$ There are now four definitions of innovation systems commonly used in the literature: national, regional, sectorial, and technological. "There are not many studies of the degree of internationalization of innovation systems. The few studies that exist show that National Innovation Systems are becoming internationalized; even if the institutions that support them remain country-specific" (Carlsson 2006).

${ }^{2}$ Open innovation has been defined as "... the use of purposive inflows and outflows of knowledge to accelerate internal innovation, and expand the markets for external use of innovation..." (Chesbrough 2003).

${ }^{3}$ The concept is proposed by C Freeman when analyzing innovations in Japan. "At the international level two contrasting experiences made a very powerful impression in the 1980s both on policy-makers and on researchers: on the one hand the extraordinary success of first Japan and then South Korea in technological and economic catch-up" (p. 10; Freeman 1995).

4"The Triple Helix indicator can be extended algorithmically, for example, with local-global as a fourth dimension or, more generally, to an $\mathrm{N}$-tuple of helices" (Leydesdorff 2012).

5“The 'Quadruple Helix' model, through which government, academia, industry, and civil society are seen as key actors promoting a democratic approach to innovation through which strategy development and decision-making are exposed to feedback from key stakeholders, resulting in socially accountable policies and practices" (Carayannis, E.G. \& Campbell 2012).

6"It is critical to consider how these innovation variables interact with one another in the context of goods and services" (Omachonu \& Einspruch 2014).

${ }^{7}$ This leads to an inclusive alternative, which underlines development based on open knowledge "make room for people to co-produce the knowledge associated with the innovations effectively in society; this implies unorthodox ways of thinking, and a lot of innovation in the design of policies" (Dutrénit \& Sutz 2014).

${ }^{8}$ In 2013, 302 patents were granted to Mexicans, that is, $3 \%$ of the total $(10,343$ patents) (IMPI, 2013). 


\section{Appendix}

Table 3 Indico index KIBS

\begin{tabular}{|c|c|c|c|c|}
\hline Issues & Max score & O, Output & Max score & C, Input capacity \\
\hline Innovations & 3,5 & & & \\
\hline Intellectual propriety & 1 & & & \\
\hline Market & 3 & & & \\
\hline Certification & 1 & & & \\
\hline Service knowledge intensity & 1,5 & & & \\
\hline $\begin{array}{l}\text { Innovation components: hardware, information, } \\
\text { and knowledge }\end{array}$ & & & 2 & \\
\hline Employees training & & & 1 & \\
\hline Employee certification & & & 1 & \\
\hline Employees studies & & & 1 & \\
\hline R\&D organization & & & 2 & \\
\hline$R \& D, \%$ of sales & & & 2 & \\
\hline Relationship with knowledge sources & & & 1 & \\
\hline Sum & 10 & & 10 & \\
\hline Indico index: average $(\mathrm{O}+\mathrm{C}) / 2$ & & & & \\
\hline
\end{tabular}

Source: Corona-Treviño 2015

\section{Acknowledgements}

I will like to thanks the DGAPA-UNAM office for the support to the research project (Papiit IN306115) and the Conacyt's initiative on the research project "Highly skilled migration", coordinated by Dr Raúl Delgado. The seminars organized through them help to developed the concept of Open National of Innovation System: ONIS. Also thanks to the CEPCYT-FE-UNAM students' paricipation on collecting and analysing the data: Blanca Borja, Aura Melèndez, Araceli Jurado, Dioselina Obispo and Alejandra Miranda.

Received: 19 December 2015 Accepted: 6 May 2016

Published online: 03 June 2016

References

Baumol, W, 2002. The free-market innovation machine: analyzing the growth miracle of capitalism. s.l.: Princenton N.J. USA: Princeton University Press,.

Burton, C. (2001). The entrepreneurial university: new foundations for collegiality, autonomy, and achievement. Higher Education Management, 13(2), 9-24

Carayannis, EG \& Campbell, DF. (2012). Mode 3 knowledge production in quadruple helix innovation systems, s.l.. Springer: SpringerBriefs in Business, 7

Carlsson, B. (2006). Internationalization of innovation systems: a survey of the literature. Research Policy, 35, 56-67.

Chesbrough, HW. (2003). The era of Open Innovation. MITSloan Management Review.

Chesbrough, H, Vanhaverbeke, W, \& West, J. (2006). Open innovation: researching a new paradigm. Oxford: Oxford University Press

Chien, CV. (2010). From arms race to the marketplace: the complex patent ecosystem and its implications for the patent system. Hastings Law Journal, 62(2), 297-356.

Coombs, R, \& Miles, I. (2000). Measurement and services: the new problematique. En: innovation systems in the service sectors. Measurement and case study analysis (pp. 85-104). Boston-Dordrecht-London: Kluwer.

Corona-Treviño, L. (2015). Indice INDICO: Innovación e las empresas. Mexico: Cepcyt DEPFE UNAM.

Davies, JL. (2001). The emergence of entrepreneurial cultures in European universities. Higher Education Management, $13(2), 25-44$.

De Jong, JWTTK. \&. HC. 2008. Policies for open innovation: theory, framework and cases, Helsinki, Finland: research project funded by VISION Era-Net.

Djellal, F, \& Gallouj, F. (2013). The productivity challenge in services: measurement and strategic perspectives. The Service Industries Journal, 33(3-4), 282-299.

Drejer, I. (2004). Identifying innovation in surveys of services: a Schumpeterian perspective. Research Policy, 33, 551-562.

Dutrénit, G, \& Sutz, J. (2014). Introduction. En: National System of Innovation, Social Inclusion and Development: the Latin American experience. Cheltenham UK: Edward Elgar Publishing.

Etzkowitz, H, \& Leydesdorff, L. (2000). The dynamics of innovation: from national systems and "mode2" to a triple helix of university-industry-government relations. Research Policy, 29, 109-123.

Freeman, C. (1995). The 'National System of Innovation' in historical perspective. Cambridge Journal of Economics, 19, 5-24.

Gassmann, O, Enkel, E, \& Chesbrough, H. (2010). The future of open innovation. R\&D Management, 40(3), 213-221. 
Gibbons, et al. (1994). The new production of knowledge: the dynamics of science and research in contemporary societies. London: Sage.

Godin, B. (2006). The linear model of innovation. The historical construction of an analytical framework. Science, Technology \& Human Values, 31(6), 639-667.

Graf, P, \& Braun, A. (2013). A policy perspective on open innovation-the Mexican case. International Journal of Entrepreneurship and Innovation Management, 17(4/5/6), 296-313.

Hertog, P. (2000). Knowledge-intensive business services as co-producers of innovation. International Journal of Innovation Management, 4(4), 491-528.

Howells, J, \& Teller, B. (2004). Innovation in services: issues at stake and trends. Manchester: University of Manchester.

Jackson, DJJ. (2011). What is an innovation ecosystem? Arlington: National Science Foundation.

Leydesdorff, L. (2012). The triple helix, quadruple helix, ..., and an n-tuple of helices: explanatory models for analyzing the knowledge-based economy? Journal of the Knowledge Economy, 3(1), 25-35.

Lundvall, B-A. (1988). Innovation as an interactive process. In G. Dosi, C. Freeman, R. Nelson, G. Silverberg, \& L. Soete (Eds.), Technical change and economic theory (pp. 349-369). London: Pinter.

Miles, I. (2008). Patterns of innovation in service industries. IBM Systems Journal, 47(1), 115-128.

OECD. (2010). SMEs, entrepreneurship and innovation. Paris: OECD.

Omachonu, VK, \& Einspruch, NG. (2014). Innovation: implications for goods and services. International Journal of Innovation and Technology Management, 7(2), 109-127.

Reis, E. (2011). The lean startup. How today's entrepreneurs use continuous innovation to create radically successful businesses. New York: Crown Business.

Schumpeter, JA. 1934. The theory of economic development: an inquiry into profits, capital, credit, interest, and the business cycle. s.l.: Transaction Publishers.

Valls, J \& otros, Y. (2012). Causas de fracaso de los emprendedores. La Coruña: Netbiblo, S. L., Oleiros Coleccion de Estudios Red Emprendia.

Vanhaverbeke, W, Van de Vrande, V, \& Chesbrough, H. (2008). Understanding the advantages of open innovation practices in corporate venturing in terms of real options. Creativity and Innovation Management, 17(4), 251-258.

Submit your manuscript to a SpringerOpen ${ }^{\circ}$ journal and benefit from:

- Convenient online submission

- Rigorous peer review

- Immediate publication on acceptance

Open access: articles freely available online

- High visibility within the field

- Retaining the copyright to your article

Submit your next manuscript at $>$ springeropen.com 